COMMENTARY

The Kaye Scholer Affair

\title{
Professor Simon on the Kaye Scholer Affair: Shock at the Gambling at Rick's Place in Casablanca
}

Jonathan R. Macey

In this issue of Law $\mathcal{E}$ Social Inquiry, Professor William Simon makes a somewhat belated, but highly valuable contribution to the literature on what he calls the Kaye Scholer "affair." By the phrase Kaye Scholer affair, Simon refers to Kaye, Scholer, Fierman, Hays, and Handlers' representation of Charles Keating and his banking empire during the heady days when savings and loan institutions broke free of all vestiges of regulatory supervision and appeared to control not only their regulators, but most of the legal and political community inside the Washington Beltway. The results were not pretty, as mismanagement and imprudent risk taking eventually led to the collapse of the savings and loan industry, the bankruptcy of its federally managed insurance system, and massive losses to U.S. taxpayers.

In his interesting comment, Simon points out, correctly, that nobody in the legal profession appears to have bothered to confront the ethical issues raised by the case. In this comment I argue that only a highly romanticized view of the legal profession could cause Simon to be surprised by the response of the legal profession. Of course the legal profession was more selfprotective than self-regulatory. It seems overly idealistic of Simon to find this remarkable. The excessive idealism of Simon's aspirational view of the legal profession is matched only by his lack of recognition of the extent to

Johnathan R. Macey is J. DuPratt White Professor of Law, and director, John M. Olin Program in Law and Economics, Cornell University. 
which thrift-industry regulators were captured and corrupted by the firms they ostensibly were supposed to be regulating.

In his article Simon expresses concern about the performance of the bar in connection with the Kaye Scholer affair. He is worried that the performance of the bar may give lawyers a bad name. Does he really think it could get worse? He seems genuinely surprised that "a broad range of professional leaders and institutions failed seriously to confront the issues raised by the OTS (Office of Thrift Supervision) in its complaint against Kaye Scholer's performance." He complains that Kaye Scholer lawyers appear to have engaged in some very shady lawyering. And he seems surprised that the legal profession largely ignored this behavior (when it wasn't actively defending the firm). As Simon correctly points out, the bar was far more concerned about the fact that the OTS had the temerity to freeze a law firm's assets in response to a series of ethics violations, than they were about the substance of the violations themselves. This, Simon argues, "should be counted as a large mark against it in the current debate about the appropriate allocation of regulatory responsibilities between public authorities and professional institutions" (1998, 245).

There is something charmingly naive about Professor Simon's perspective on the bar. Like the student editors of the Southern California Law Review, Simon is concerned with the question "[w]as Kaye-Scholer's conduct in its representation of Lincoln ethical?" (Southern California Law Review 1993, 978). And Professor Simon seems genuinely perplexed that so few others within the legal profession seem to care.

Of course Simon is right that the performance of the bar was outrageous in the unseemly way it rushed to the defense of the thrift lawyers in Kaye Scholer. Outrageous, yes. Surprising, no. After all, this is the same bar that has, for all practical purposes, refused to police itself for years. This is the same bar whose members routinely negotiate settlements of large, class action lawsuits in which the lawyers get million dollar fees and the clients get coupons for discounts to buy more of the products that caused their injuries (Torry and Brown 1995; Sanchez and Nauss, 1995). This is the same bar that has refused to do anything about what is perhaps the most outrageous class action settlement of all time-the settlement in the BancBoston mortgage escrow case, Hoffman v. BancBoston Mortgage Corp., No. 91-1880 (Ala. Cir. Ct. Jan. 24, 1994), in which the class members had to pay attorneys' fees under a formula that allowed class members to suffer a net out-of-pocket loss (Koniak and Cohen 1996, 1061-62).

It is no surprise why the legal profession is in such a sorry state. The American Bar Association is a special interest group that single-mindedly pursues the narrow self-interest of its ruling coalition, regardless of the costs to society. The ABA favors rules that increase the demand for lawyers' services, and opposes reforms that would decrease litigation, despite the 
general perception that the civil liability system is out of control. That is why the $\mathrm{ABA}$ is consistently antibusiness in its outlook and orientation.

The legal profession does not enjoy the trust or the respect of the public. Raw political power is what allows the lawyers to retain regulatory control over their own profession. It is naive for Simon to think differently. The legal profession in the United States is far beyond the point at which lawyers are seen as agents of good, with a "special responsibility for the quality of justice." Lawyers are viewed as part of the problem as often as they are part of the solution. Indeed, over 60 years ago, a leading legal academic was able confidently to pronounce that the "historic view was that a lawyer was an officer of the court and therefore an integral part of the scheme of justice. But the conception of the lawyer now obtaining is that he is the paid servant of his client, justified in using any technical lever that the law supplies in order to forward the latter's interest" (Berle 1933, 342). While those words were written in 1933, I think that Simon would agree that this is a fair description of the lawyers' conduct in the Kaye Scholer case.

The Kaye Scholer affair represents the pinnacle of what might be described as the "contextual" approach to legal ethics. According to the contextual approach, "ethical deliberations take place within the specific context of a representation, and context can undermine arguments based on universally applicable legal rules. Conduct that is appropriate for a litigator may not be appropriate for a lawyer assisting a client in a bank examination or for a White House Counsel charged with responding to an investigation by the Justice Department" (Painter 1998, 2). The contextual approach is most closely identified with Harvard Professor David Wilkins, one of America's most respected ethicists. Wilkins probably did not intend for his description of lawyers' ethical duties to be used as a mechanism for generating excuses for all sorts of unethical behavior. And I would be very surprised if he had in mind Professor Geoffrey Hazard's 22-page expert opinion's statement supporting Kaye Scholer's behavior on the theory that Kaye Scholer was "litigation counsel" for Charles Keating, and therefore enjoyed some sort of "Get Out of Jail Free" card with respect to ethical violations.

At its core, Professor Simon's article tries to make the point that the Kaye Scholer case was less ambiguous than Kaye Scholer's defenders would have us believe. But the assertion that the case was clear from a moral perspective depends critically on which version of the facts one embraces. $\mathrm{Si}$ mon asserts that the case is a run-of-the-mill ethics case that does nothing other than assert the old-fashioned principle that the "lawyer who cannot do anything for a client that would not further his frauds should withdraw" $(1998,244)$. But three paragraphs later, Simon appears to have recanted this view, conceding that a "major obstacle to appraising Kaye Scholer's conduct that may have inhibited discussion, especially by those inclined to be sympathetic to the charges, is that we have limited knowledge of the 
facts" $(1998,245)$. Simon attempts to remove himself from this impasse by arguing that he will simply accept the accuracy of the OTS's pleadings for the purposes of his analysis. But he concludes, as he must, that since the case was settled, it "seems impossible to reach definite conclusions about the ultimate merits on this mooted record" $(1998,245)$.

This analysis has two problems. First, Simon appears to conflate the actions of Kaye Scholer with the action of its client, Lincoln. For example, at one point savings and loan associations, including Lincoln, were prohibited by Congress from making certain real estate investments. A "grandfathering" exception was made for investments that were finalized before a certain date. Lincoln tried to argue that a large number of its real estate investments were permissible because they were made early enough in time to qualify under this grandfathering exception. To support this claim, Lincoln used documents prepared after the cutoff date but backdated and written in the present tense to create the impression that they had been written beforehand. No one disputes that if Kaye Scholer had participated in this fraud, it would have violated its professional responsibilities. The issue is whether Kaye Scholer knew of the backdating and other fraudulent activities when it gave its opinion that Lincoln had met the requirements of the grandfathering provisions of the statute.

After all, if the regulators could be fooled by Lincoln, why couldn't its lawyers be fooled as well? In other words, as is so often the case, our analysis of Kaye Scholer's conduct does not turn on our evaluation of the rules of ethics. It turns on our articulation of the relevant facts. And Simon readily admits that the facts are very much in dispute. I hasten to add that this analysis does not detract from Simon's basic point that something is very strange about the eerie silence of the bar. Surely some prominent member of the bar should have come forward long ago to say that if the allegations against Kaye Scholer were true, then it had stepped way, way over the line. Maybe this was never done because the point was so obvious. But I think that Simon probably is right to say that it seems more likely that the bar was acting to protect one of its own.

Another problem with Simon's analysis is that his effort to treat the Kaye Scholer affair as a garden-variety ethics case fails to account for the rather bizarre litigation tactic used by the Office of Thrift Supervision, namely the freeze placed on the firm's assets. As Simon points out, most lawyers who have written about the Kaye Scholer affair have focused on the asset freeze. I suppose it is natural for Simon, as an ethicist, to say that we have paid far too much attention to the asset freeze relative to the core issues surrounding the basic ethics of Kaye Scholer's behavior. On the other hand, he acknowledges that once there is basic agreement about the relevant facts, the ethical issues involving Kaye Scholer seem pretty straightforward. But what about the ethics of the government lawyers involved in the case? 
Are government lawyers not bound by ethical rules? In other words, even if we assume that Kaye Scholer had acted unethically, where was their legal authority to freeze Kaye Scholer's assets??

The legal authority to freeze assets in the bank failure context is contained in 12 U.S.C. $\$ 1818$ (c)(1)(Supp. 1990). This statutory provision was meant to empower regulators to freeze the assets of troubled banks and thrifts before those assets disappear (Coffee 1992). The statute makes it clear that freeze orders are supposed to be issued only to prevent actions that are likely to have adverse effects on insured financial institutions (Macey and Miller 1993, 1135). But since the depository institution in question was seized by the FDIC in April 1989, and the freeze against Kaye Scholer was not imposed until March 1992, the government lawyers were obviously not using the asset freeze to protect the assets of an insured depository institution from disappearing on the eve of regulatory intervention. A more plausible explanation for the actions of the government lawyers is that they were abusing their statutory authority in order to gain the leverage over Kaye Scholer necessary to compel them quickly to settle the lawsuit. And, of course, the strategy was successful, from the perspective of the government lawyers. Kaye Scholer was forced to settle shortly after the freeze was imposed.

Why did the government believe it was necessary to use these strongarm tactics? The most plausible explanation is that they lacked confidence in their ability to prevail on the merits if no settlement could be reached. This explanation is relevant in light of the highly disputed nature of the facts. If this explanation of their behavior is correct, the concerns of the organized bar seem more plausible. Moreover, if this explanation is correct, it seems that Professor Simon would be justified in evaluating the ethical conduct of the government lawyers with the same attention that he gives to the ethical conduct of Kaye Scholer.

For some reason, Simon appears to have a blind spot when it comes to the ethics of government lawyers. He spends a large portion of his article criticizing my joint work with Geoffrey Miller, as well as the work of our former colleague Daniel R. Fischel, for our "moralistic, conclusory denunciations of public officials" (Simon 1998, 274). He takes particular issue with our view that taxpayer losses from the banking crisis can be attributed in large part to corruption within government regulatory agencies. Here again I find two flaws with Simon's analysis. The first is his assumption that corruption in government and corruption at Kaye Scholer are mutually exclusive possibilities. But this is not the case. Clearly it is possible (and I think likely) that ethical lapses occurred on both sides.

Second, Professor Simon does not seem to understand the pattern of regulatory abuses that characterized the banking industry during the 1980 s. In this context it is worth noting the disproportionately large number of 
political scandals in the United States since Richard Nixon's resignation over the Watergate scandal that have involved corruption in the banking industry. In addition to the scandal involving the so-called Keating Five senators, the resignation of House Speaker Jim Wright and Congressman Tony Coelho, and the Whitewater scandal involving President and Mrs. Clinton have all involved precisely the same issues. In each of these cases, politicians were accused of accepting money or promises of political support in exchange for efforts to delay the closure of failed depository institutions controlled by a well-connected political crony.

Delaying closure of failed depository institutions is against public policy because delay dramatically increases the costs of resolving such failures. Delay permits bank and thrift owners to continue to gamble with depositors' (federally insured) money. Delay gives crooked thrift operators the chance to steal more money. And delay makes it harder for regulators to collect on the loans made by the institution.

Charles Keating used his political influence to cause five United States Senators to intercede on his behalf with federal regulators in April 1987 and delay the closing of Lincoln. Using his political influence also, Keating succeeded in having regulatory jurisdiction over Lincoln switched from the tough and honest regulators in San Francisco, to the politically malleable and ill-informed regulators in Washington. In fact, even before Kaye Scholer became involved in the Lincoln case, the regulators in San Francisco were aware that Lincoln was in financial difficulty. At best, Kaye Scholer's obstructionist, pit-bull legal tactics complemented the political maneuvering that Lincoln was using to delay the closure of his bank.

Professor Simon may have a term of art for the political shenanigans that allowed the Lincoln investigation to be removed from San Francisco to Washington. I call it corruption. In the end, Simon's attempt to defend the government officials in the Lincoln affair collapses under the weight of its own incoherence. He finally admits that lawyers' norms of zealous, adversarial representation "are premised on the adequate representation of other affected interests and the participation of honest, competent government officials. No one could insist more strongly than Macey, Miller, and Fischel have that these preconditions were not fulfilled in the S\&L fiasco" (1998, 280).

I agree with Simon on this point, and I also agree with his further point that Kaye Scholer's conduct did not fit the ethical model in which two sides are represented by equally zealous officials. But how was this Kaye Scholer's fault? Are lawyers really bound to withdraw if they think the other side is represented by a lawyer who is compromised by political pressure? Clearly Kaye Scholer was not bound to withdraw simply because they knew or suspected that thrift regulators were facing political pressure to ignore Lincoln's problems. Clearly the government lawyers involved in these cases are 
independent ethical agents with responsibility for their own actions. Simon is right to say that the regulators were in a difficult position due to the fact that Congress, as well as Danny Wall, the chairman of the Bank Board, did not support their efforts. But if Simon is correct in saying that Kaye Scholer had an ethical duty to resign if it could do nothing but further a fraud, why doesn't the same hold true for the government lawyers involved in the case? Don't the ethics rules apply to them too?

Again, I wish to emphasize that I agree with both of Professor Simon's basic points: first, that it is worth focusing on the ethics of Kaye Scholer's representation of Lincoln and Charles Keating, and second, that it is worth noting how strange it is that so few commentators have addressed this issue in detail. Thus, I disagree with Simon only in fairly limited ways.

First, I think that he romanticizes the legal profession, and its ability to police itself. I find the defensiveness of the profession predictable, if depressing. Having agreed with Simon on the core point of his article, I must add that the disputed nature of the facts surrounding Kaye Scholer's activity presents more difficulties for his analysis than he admits to. Next, I do not understand why Simon feels compelled in his article to defend the behavior of the government. To say that certain politicians and government officials acted in corrupt and irresponsible ways that greatly increased the cost of the thrift bailout seems uncontrovertible as a matter of history. More important, it does not conflict with his arguments about Kaye Scholer. It is certainly possible for both Kaye Scholer and the government to have acted inappropriately. These are not, after all, mutually exclusive possibilities.

It is exceedingly strange that Simon does not recognize this. Suppose, for example, that a law firm representing a thrift institution had paid a bribe to thrift regulators to induce them to refrain from closing down an insolvent thrift. Obviously there would be culpability on both sides. The analysis would be no different if regulators succumbed to political pressure to keep an insolvent thrift open, and used the false reports of a law firm as their pretense for doing so. As Geoffrey Miller and I have observed before:

Of course, just because Lincoln already was insolvent at the time Kaye, Scholer came onto the scene does not mean that the firm's aggressive activities on the part of its client did not make things worse. In fact, Kaye, Scholer's activities could have dramatically increased the costs of the Lincoln bailout by postponing the closure of that institution and thereby allowing its losses to mount. On the other hand, it must be emphasized that Kaye, Scholer's lawyering was not all that prevented the timely closure of Lincoln. (Macey and Miller 1993, 1119)

Thus, contrary to Professor Simon's assertions, Miller and myself did not attempt to blame the regulators as a way of deflecting blame from Kaye Scholer. In contrast, it appears that it is Simon who is attempting to blame 
Kaye Scholer to the exclusion of the regulators. My point now, as then, is that there is plenty of blame to go around. Both parties are culpable. And, like the behavior of Kaye Scholer, the actions of the government regulators have received far too little scrutiny.

\section{REFERENCES}

Berle, A. A. Jr. 1933. The Legal Profession and Legal Education. Vol. 9 of Encyclopedia of the Social Sciences 340-45.

Coffee, John C. Jr. 1992. Due Process for Kaye, Scholer? Legal Times, 16 March, 22.

Koniak, Susan, and George M. Cohen. 1996. Under Cloak of Settlement. Virginia Law Review 82:1051-1280.

Macey, Jonathan R., and Geoffrey P. Miller. 1993. Kaye, Scholer, FIRREA, and the Desirability of Early Closure: A View of the Kaye, Scholer Case from the Perspective of Bank Regulatory Policy. Southern California Law Review 66:1115-1143.

Painter, Richard W. 1998. Letter to William H. Simon, 4 January. Copy on file with author.

Sanchez, Jesus, and Donald W. Nauss. 1995. Court Rejects GM Settlement on Value of Pickup Trucks. L. A. Times, 18 April, D6.

Simon, William. 1998. The Kaye Scholer Affair: The Lawyer's Duty of Candor and the Bar's Temptations of Evasion and Apology. Law and Social Inquiry 23:243-95.

Southern California Law Review. 1993. Introduction: Kaye, Scholer and the OTS: Did Anyone Go Too Far? Southern California Law Review 66:977-984.

Torry, Saundra, and Warren Brown. 1995. GM Truck Settlement Overturned on Appeal. Washington Post, 18 April, D1. 